から撜褐色に変化する。放置後水水中にあけて析出する䙖色沈殿 ならびに黑裪色樹脂状物質をエーテル層に移し，前同様に処理し $\tau \operatorname{mp} 147^{\circ} \sim 148^{\circ} \mathrm{C}$ の白色結晶(II) $1.2 \mathrm{~g}$ を得た（收率 $46 \%$ )。 アルコフルから 再結晶して mp $150^{\circ} \sim 151^{\circ} \mathrm{C}$ 。アルカりによる 加水分解で $\alpha$-ナフトールと $\beta$-メチルケイ皮酸とを生成し，壏化 酸および壏酸一マグネシウム呈色負である。

分析值 C $83.56 \%, \mathrm{H} 5.31 \%$

$\mathrm{C}_{80} \mathrm{H}_{18} \mathrm{O}_{2}$ としての計算值 C $83.31 \%$, H $5.59 \%$ 紫外吸収極大の波長 $(\mathrm{m} \mu) \quad 230,290$

\subsection{B-ナフトールと $a$-エチルケイ皮酸との反応生成物 (IV)}

$\beta$-ナフトール $1.4 \mathrm{~g} ， \alpha$-エチルケイ皮酸 $1.7 \mathrm{~g}$ (共に 0.01 mol) およびポリリン酸 $(n=2.5) 20 \mathrm{~g}$ の混合物を沸とう湯浴 上で 1.5 時間加熱する。反応液は黄橙 $\rightarrow$ 橙 $\rightarrow$ 褐橙色と縵漫な変化 をたどる。放置後水水中にあけ，析出する黄色沈殿から前同様に 処理して黄橙色樹脂状物資を得，これをアルコールで洗い，残存 する微量の油状物を除き，水を滴加して放置すると黄色結晶 $\mathrm{mp}$ $70^{\circ} \sim 78^{\circ} \mathrm{C}$ が析出する。アルコールから再結晶して 白黄色結晶 (IV) $\mathrm{mp} 80^{\circ} \sim 81^{\circ} \mathrm{C}$ となる。収量 $0.8 \mathrm{~g}(30 \%)$ 。塩化鉄および 塭酸ーマグネシウム呈色ともに垻で，アルカリによる加水分解を 受ける。

分析值 C $83.78 \%$, H $6.19 \%$

$\mathrm{C}_{21} \mathrm{H}_{18} \mathrm{O}_{2}$ としての計算值 C $83.42 \%$ ，H 6.00\%

紫外吸収極大の波長 $(m \mu) \quad 230,288$
1.5 ピロカロールとヒドロケイ皮酸との反応生成物（V)

ピロガロール $1.3 \mathrm{~g}$ ，ヒドロケイ皮酸 $1.5 \mathrm{~g}$ (ともに $0.01 \mathrm{~mol}$ ) およびポリリン酸 $(n=2.5) 20 \mathrm{~g}$ の混合物を洲とう湯浴上で 25 分間反応させる。反応液は黄橙 $\rightarrow$ 赤橙 $\rightarrow$ 深赤 $\rightarrow$ 哚紅とす夕やか几 変色する。放置後水置後水水中にあけ，析出する赤色沈殿をデカ ンテーションして，沈殿部と少量の残液とをェーテル抽出して黒 赤色樹脂状物質を得，希アルコールで洗い，放置後口過して淡桃 色結晶(V) $\mathrm{mp} 78^{\circ} \sim 82^{\circ} \mathrm{C}, 0.2 \mathrm{~g}$ を得た。收率 $8 \%$ 。乙れを 50 $\%$ アルコールから再結晶すると $\mathrm{mp} 86^{\circ} \sim 87^{\circ} \mathrm{C}$ となる。浱硫酸 で赤色を呈し，アルカリに溶け黄色，鉄で灰褐色に着色する。 分析值 C $65.48 \%, \mathrm{H} 5.88 \%$

$\mathrm{C}_{15} \mathrm{H}_{14} \mathrm{O}_{4} \cdot \mathrm{H}_{2} \mathrm{O}$ としての

計算值 C $65.22 \%, \mathrm{H} 5.79 \%$

無水物 分析值 C $69.92 \%, \mathrm{H} 5.55 \%$

$\mathrm{C}_{15} \mathrm{H}_{14} \mathrm{O}_{4}$ としての計算值 C $69.75 \% ， \mathrm{H}_{1} .5 .46 \%$

紫外吸収極大の波長 $(\mathrm{m} \mu) \quad 345$

別に Dutta尚の方法にしたがい，ピロガロールとヒドロケイ皮 酸との混合物を無水塩化亜鉛の存在下に, $115 \sim 120^{\circ} \mathrm{C}$ で 2 時間 加熱して得た $2,3,4$-トリオキシー乔ーベンジルアセトフェノン mp $86^{\circ} \sim 87^{\circ} \mathrm{C}$ とV との混融結果, 同一物と認めた。

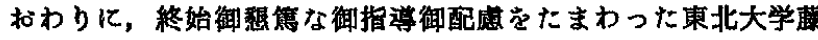
瀬新一郎教授に厚く感謝いたします。

\title{
$\longrightarrow-1-$ \\ 9-ニトロアントラセンの双㮌子モーメントと赤外吸収スペクトル
}

（昭和 36 年 8 月 9 日受理）

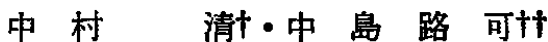

芳香族ニト口化合物の，二トロ基に関する 振動については, $\mathbf{N}-\mathbf{O}$ 伸縮振動に関しては多数の報告があり，著者らの 1 人もこ れについて広く研究を行なっているが1)， C-N 伸縮振動， $-\mathrm{NO}_{2}$ 変角振動などについては明らかでない。今回，9-ニトロアントラ センの配向結晶による赤外二色性について測定を行ない，振動の 㱕属を行なったので報告する2。また本物筫の双極子モーメント についてる測定を行なったので合わせて報告する。

Trotter は 9-ニトロアントラセンについて, X 線による結晶 解析》，および赤外吸収せの測定を行なっており，X線による結 晶解析の結果によれば，アントラセン面は，ほほ平行層状になら び- $\mathrm{NO}_{2}$ 基はアントラセン面に対して，安定位置 $85^{\circ}$ の傾きをむ

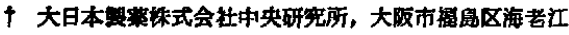

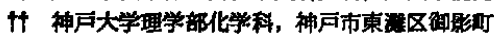

1） a）日化第11年会，6089，6090；b) 日化 第12年会，4076；c) 日化第 13年会 7 N 87.7 N 88; d) 赫ラマン討䇶会（第 6 回 33.34 (1959)；e） 同会（第 7 回 14 B3 (1960)) はどで報告.

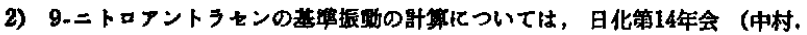

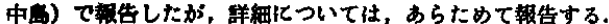

3) J. Trotter, Acta. Cryst. 12, 237 (1959),

4) J. Trotter, Can. J. Chem. 37, 1487 (1959).

つている。立た赤外吸収スペクトルについては, N-O 伸縮振動, $\mathrm{C}-\mathrm{N}$ 伸縮振動の㷌属を行なっているが, $\mathrm{C}-\mathrm{N}$ 伸縮振動の㷌属 については, われわれの結果とは異なっている。

9-ニトロアントラセンの配向結晶は, $5000 〜 400 \mathrm{~cm}^{-1}$ におい

表 19 9-ニトロアントラセンの吸収波数と振動の㷌属

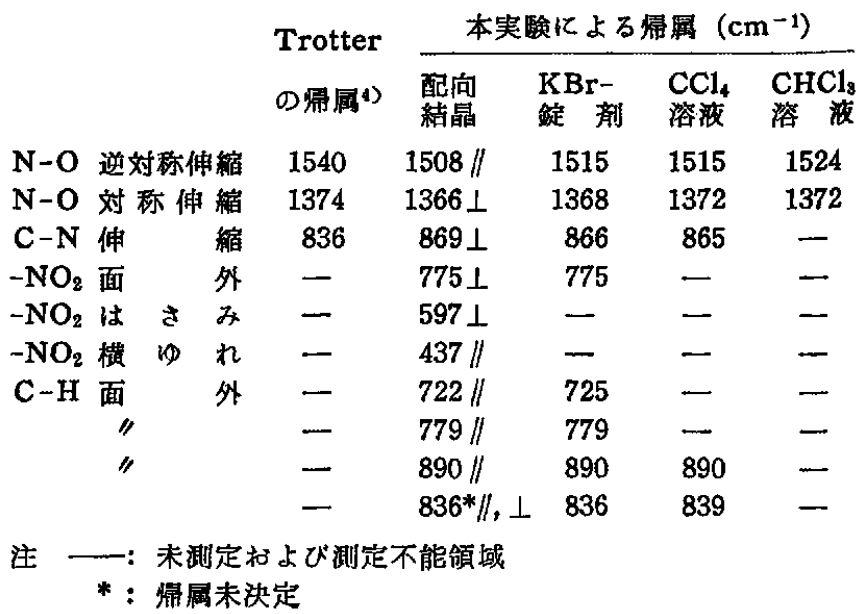


$\mathrm{NaCl}$ プリズム領域

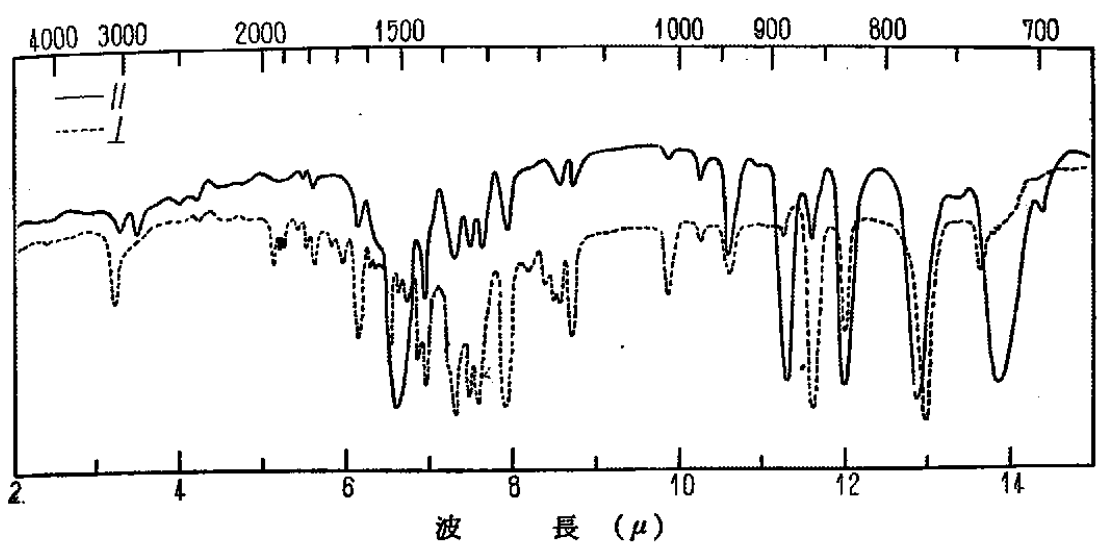

网 19 -ニトロアントラセンの赤外二色性スペクトル

(Perkin-Elmer 21 型赤外分光器による)

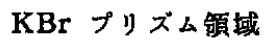

波数 $\left(\mathrm{cm}^{-1}\right)$

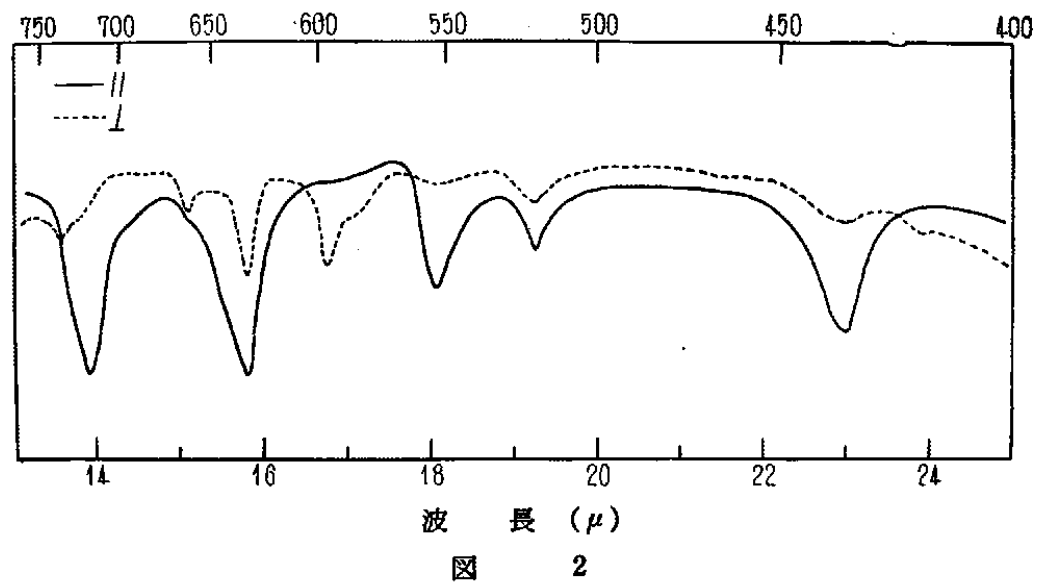

C-N 伸縮振動については, Trotter は $836 \mathrm{~cm}^{-1}$ に㷌属しているが，われわれの赤 外三色性の測定からは $869 \mathrm{~cm}^{-1}$ が妥当で, $836 \mathrm{~cm}^{-1}$ のバンドは, 平行, 垂直両成分を むち州属は明らかでない。その他のバンドに ついては, 表1のように㷌属を行なった。つ ぎに，9-ニトロアントラセンの双㥛子モーメ ントは共鵬法の回路を用いて，ベンゼン溶液 として測定した。測定温度は， $25^{\circ} \pm 0.01^{\circ} \mathrm{C}$ で行なった。

測定結果を表 2 に示す。

表 2 9-ニトロアントラャンの 双極子モーメント

$\begin{array}{cccc}\omega & \varepsilon & d & n_{\mathrm{D}}^{2} \\ 0.00000 & 2.2725 & 0.8738 & 2.2424 \\ 0.00518 & 2.3115 & 0.8755 & 2.2449 \\ 0.01034 & 2.3447 & 0.8769 & 2.2475 \\ 0.01512 & 2.3807 & 0.8782 & 2.2500 \\ 0.02030 & 2.4188 & 0.8797 & 2.2529 \\ 0.02523 & 2.4546 & 0.8811 & 2.2552\end{array}$

$a=7.22, b=0.29, c=0.51$, $P_{2 \infty}=353.96, P_{E}+P_{A}=1.05 M R_{D}$ $=75.29, \quad P_{0}=278.67, \mu=3.69 D$ (ニトロベンゼン: $\mu=3.97 D$ )

立体障害によりニトロ基の共鳴モーメント は减少し，双極子モーメントは立体障害のな いるのにくらべると小さくなるあ。9-ニトロ アントラセンの双極子モーメント; $\mu=3.69$ $D$ は, ニトロベンゼン $(3.97 D)$ との差がわ すが $0.28 D$ で, ニトロベンゼンとの簡単 な比較からは立体障害はあまり大きくないように思われるが，9アンスロールのモーメントからの類推では, 9-ニトロアントラセ ンのニトロ基とアントラセン核が同一平面にあるときにはこの化 合物の 双極子モーメントは $4.4 D$ くららい推測される7ので, これを考虑に入れれば，平面構造の場合の予想值と，9-ニトロア ントラセンの双極子モーメントの実験值との差は，約 $0.7 D$ とな り 9)，1，8-位置の水素によるニトロ基への立体障害がかなり大き いことを示している。

本実験に用いた試料は，Dimroth のの方法によって合成した。 $\mathrm{mp} 148^{\circ} \mathrm{C}$ (エタノールから再結晶)。

終りに赤外吸取スペクトルの解析について, 種々御指然いただ いた東京大学理学部島内武彦教授, 㮔々御指導下さった神戸大学 理学部衣笠俊男教授に厚く御礼申し上げます。

(1961 年 4 月, 日本化学会第 14 年会 (一部) 䜊演)

6) たとえぱ J. W. Smith, "Steric effects in cojugated systems" p. 141 (1958) ed. G. W. Gray, Butterworths Pub. Ltd.

7) 西本吉助氏 (大阪市立大学理学部) の积信飞上る。

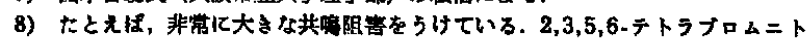

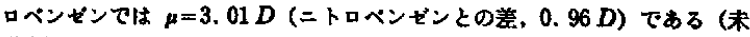
発表).

9) O. Dimroth, Ber. 34, 219 (1901).

5) 衣篮, 中禹，目化 82，1473 (1961). 